\title{
Effect of dextran and dextran sulfate on the structural and rheological properties of model acid milk gels
}

\author{
U. Pachekrepapol, ${ }^{*}$ D. S. Horne, $\dagger$ and J. A. Lucey $\dagger^{1}$ \\ *Department of Food Science, and \\ †Wisconsin Center for Dairy Research, University of Wisconsin-Madison, 1605 Linden Drive, Madison 53706
}

\begin{abstract}
Various types of polysaccharides are widely used in cultured dairy products. However, the interaction mechanisms, between milk proteins and these polysaccharides, are not entirely clear. To explore the interactions between uncharged and charged polysaccharides and the caseins, we used a model acid-milk-gel system, which allowed acidification to occur separately from gelation. The effect of adding uncharged dextran (DX; molecular weight $\sim 2.0 \times 10^{6} \mathrm{Da}$ ) and negatively charged dextran sulfate (DS; molecular weight $\sim 1.4 \times$ $\left.10^{6} \mathrm{Da}\right)$ to model acid milk gels was studied. Two concentrations (0.075 and $0.5 \%$, wt/wt) of DX or DS were added to cold milk $\left(\sim 0^{\circ} \mathrm{C}\right)$ that had been acidified to $\mathrm{pH}$ values $4.4,4.6,4.8$, or 4.9 . Acidified milks containing DX or DS were then quiescently heated at the rate of $0.5^{\circ} \mathrm{C} / \mathrm{min}$ to $30^{\circ} \mathrm{C}$, which induced gelation, and gels were then held at $30^{\circ} \mathrm{C}$ for $17 \mathrm{~h}$ to facilitate gel development. Dynamic small-amplitude-oscillation rheology and large-deformation (shear) tests were performed. Microstructure of gels was examined by fluorescence microscopy. Gels made with a high concentration of DX gelled at a lower temperature, but after $17 \mathrm{~h}$ at $30^{\circ} \mathrm{C}$, these gels exhibited lower storage moduli and lower yield-stress values. At $\mathrm{pH} 4.8$ or 4.9 (pH values greater than the isoelectric point of caseins), addition of $0.5 \%$ DS to acidified milk resulted in lower gelation temperature. At $\mathrm{pH} 4.4$ ( $\mathrm{pH}$ values less than the isoelectric point of caseins), addition of $0.5 \%$ DS to acidified milk resulted in gels with very high stiffness values. Gels made at $\mathrm{pH} 4.8$ or 4.9 with both concentrations of DS had much lower stiffness and yield-stress values than control gels. Microstructural analysis indicated that gels made at $\mathrm{pH} 4.4$ with the addition of $0.5 \%$ DX exhibited large protein strands and pores, whereas gels made with $0.075 \%$ DX or the control gels had a finer protein matrix. At higher $\mathrm{pH}$ values $(>4.4)$, gels made with $0.5 \%$ DX had a finer structure. At all $\mathrm{pH}$
\end{abstract}

Received July 25, 2014.

Accepted January 23, 2015.

${ }^{1}$ Corresponding author: jlucey@cdr.wisc.edu values, gels made with $0.5 \%$ DS exhibited larger pores than the control gels. This study demonstrated that low concentrations of uncharged DX did not significantly affect the rheological properties of model acid milk gels; high concentrations of DX resulted in earlier gelation, possibly caused by depletion-induced attractions between casein particles, which altered the microstructure and created weaker gels. At $\mathrm{pH}$ values $<4.6$, negatively charged DS produced stiff casein gels, which might be due to attractive crosslinking by electrostatic interactions between $\mathrm{DS}$ and caseins at $\mathrm{pH}$ values below the isoelectric $\mathrm{pH}$ of casein (i.e., positively charged casein regions interacted with negatively charged DS molecules).

Key words: dextran, dextran sulfate, exopolysaccharide, acid milk gel, stabilizer

\section{INTRODUCTION}

Important physical characteristics of yogurts for consumers include the lack of visual whey separation on the yogurt surface and its (perceived) viscosity, and these properties can influence the overall consumer acceptance of set-style yogurts (Lee and Lucey, 2010). In practice, these attributes can be controlled by the addition of dried dairy ingredients to increase the total milk solids content or by the addition of stabilizers, such as pectin, gelatin, or starch (Tamime and Robinson, 2007). Some lactic acid bacteria used in yogurt production are able to produce exopolysaccharides (EPS), which can affect the texture and viscosity of yogurts (Ruas-Madiedo et al., 2002). EPS can be uncharged, or negatively charged due to the presence of groups such as phosphate or acetate (Girard and Schaffer-Lequart, 2008).

When milk is fermented, lactose in milk is converted into lactic acid, leading to a reduction in $\mathrm{pH}$. As $\mathrm{pH}$ decreases, the colloidal calcium phosphate of casein micelles is solubilized and the net negative charge of casein micelles is reduced, resulting in aggregation of caseins as they approach their isoelectric point (pI) around pH 4.6 (Lucey and Singh, 1997). At the beginning of fermentation, the $\mathrm{pH}$ of milk is higher than 
the pI of casein, so negatively charged or uncharged EPS do not associate with casein micelles, but at this $\mathrm{pH}$ the presence of both types of polysaccharides could cause phase separation (Tuinier and de Kruif, 1999). Depletion flocculation by uncharged polysaccharides can induce flocculation of casein micelles, which can cause phase separation (de Kruif and Tuinier, 2001). As the $\mathrm{pH}$ of milk decreases, casein particles and negatively charged polysaccharides may experience attractive electrostatic interactions due to increasing number of positive charges or patches on caseins (Girard and Schaffer-Lequart, 2008). Studies on the effect of uncharged and negatively charged EPS or polysaccharides on textural properties of yogurt are limited, however, and the results have been inconclusive (Purohit et al., 2009; Kristo et al., 2011; Mende et al., 2012). Acidinduced gelation of milk (by glucono- $\delta$-lactone) was used by Aichinger et al. (2007) to kinetically trap a phase separating system of milk and xanthan gum into various types of mixed gel structures.

Acidification rate can greatly affect rheological and physical properties of acid milk gels (Lucey and Singh, 1997; Lee and Lucey, 2004). Each starter strain exhibits a specific acidification rate during growth, dependent on conditions, such as incubation temperature and type of growth medium.

In this study, dextran (DX) and dextran sulfate (DS) were selected as models for uncharged and negatively charged polysaccharides, respectively. Dextran was used in the study because it is a homoexopolysaccharide produced from Leuconostoc mesenteroides that can be obtained in purified form with various known molar masses. Dextran is composed of glucose subunits, which are linked by $\alpha(1 \rightarrow 6)$ linkages on its main chain and $\alpha(1 \rightarrow 3)$ linkages on its side chain. Dextran sulfate is a derivative of DX with added sulfate groups $\left(\mathrm{SO}_{3}{ }^{-}\right)$ giving negative charges to the polymer molecules. Dextran sulfate has been reported to form complexes with caseins through electrostatic interactions even at very low pH levels; that is, pH 2 (Jourdain et al., 2008).

The objective of this research was to better understand the effect of uncharged and negatively charged polysaccharides on the rheological and microstructural properties of acid milk gels made at different $\mathrm{pH}$ levels. In this study, we used a system with the cold, acidified milk model developed by Roefs et al. (1990). This model gel system allows for the separation of the acidification and gelation processes, and gels can be prepared at various specific $\mathrm{pH}$ values (without the complication of differing acidification rates). Milks were cooled to $\sim 0^{\circ} \mathrm{C}$ and acidified to low $\mathrm{pH}$ values in the cold to inhibit gelation. At low temperature $\left(\sim 0^{\circ} \mathrm{C}\right)$, acidified milks do not gel, probably because $\beta$-caseins protrude from the surface of casein particles providing steric repulsion (Roefs et al., 1990). We recently studied the interactions between caseins and DX and DS in cold, acidified milk dispersions (Pachekrepapol et al., 2014). High concentration of DX induced depletion flocculation. At $\mathrm{pH}>\mathrm{pI}$, DS caused loss of turbidity or greater dispersion of caseins. The $\mathrm{pH}$ range between 4.4 and 4.9 was selected in our study to have gels at $\mathrm{pH}$ values above and below the $\mathrm{pI}$ of caseins. At $\mathrm{pH}$ values higher than 4.9 , (unheated) milk generally does not form an acidinduced gel, whereas at $\mathrm{pH}$ values lower than 4.4 , gelation may occur spontaneously even at $\sim 0^{\circ} \mathrm{C}$ (Roefs et al., 1990). In this study, we investigated gels made from cold, acidified milks and studied the effect of adding various concentrations of DX or DS to acidified milk on the gelation temperature, rheological properties, and microstructure of the acid milk gels.

\section{MATERIALS AND METHODS}

\section{Sample Preparation}

Reconstituted skim milk and DX and DS solutions were prepared as described by Pachekrepapol et al. (2014). Reconstituted skim milk was prepared by dispersing $12 \mathrm{~g}$ of low-heat, nonfat dry milk powder in $100 \mathrm{~g}$ of deionized water. The solution was stirred at $\sim 25^{\circ} \mathrm{C}$ using a magnetic stirring unit overnight (16-20 h) before use. To inhibit bacterial growth, $100 \mathrm{mg} / \mathrm{L}$ of thiomersal $\left(\mathrm{C}_{2} \mathrm{H}_{5} \mathrm{HgSC}_{6} \mathrm{H}_{4} \mathrm{COONa}\right.$, Sigma-Aldrich, St. Louis, MO) was added as a preservative. Dextran (Sigma-Aldrich) with average molar mass of $\sim 2 \times 10^{6}$ Da from Leuconostoc mesenteroides and DS (MP Biomedicals, Solon, $\mathrm{OH})$ with molar mass of $\sim 1.4 \times 10^{6}$ $\mathrm{Da}$ and charge density of 1.9 sulfate groups per glucosyl residue were prepared by dispersing in deionized water to make $10 \%$ (wt/wt) stock solutions. Thiomersal was added to inhibit bacterial growth. The solutions were stirred for $3 \mathrm{~h}$ at $\sim 25^{\circ} \mathrm{C}$ and then heated in a water bath at $85^{\circ} \mathrm{C}$ for $5 \mathrm{~min}$. These solutions were stored in an ice water bath until use.

Reconstituted skim milk was cooled in a water bath (with ice) to $\sim 0^{\circ} \mathrm{C}$ for $30 \mathrm{~min}$ before acidification. Cooled milk was acidified by the addition of $3 \mathrm{~N} \mathrm{HCl}$ until the $\mathrm{pH}$ decreased to $4.9,4.8,4.6$, or 4.4. The $\mathrm{HCl}$ was gradually added in $100-\mu \mathrm{L}$ increments with 1-min intervals. The $\mathrm{pH}$ of milk was measured by a pH meter, Accumet Basic AB 15plus (Fisher Scientific, Pittsburgh, PA). After acidification, DX or DS solution was added to give final concentrations of 0.075 or $0.5 \%$ (wt/wt), and the temperature was maintained at $\sim 0^{\circ} \mathrm{C}$. These concentrations were selected based on our previous study (Pachekrepapol et al., 2014). 


\section{Gel Preparation and Rheological Analysis}

Cold, acidified milks were warmed and gelled using a rheometer, Universal Dynamic Spectrometer (Paar Physica UDS 200, Physica Messtechnik GmbH, Stuttgart, Germany) as described by Lee and Lucey (2004). The cup and bob measuring geometry (Z3 DIN) was maintained at $\sim 0^{\circ} \mathrm{C}$. Fourteen millimeters of cold milk $\left(\sim 0^{\circ} \mathrm{C}\right)$, containing DX or DS, were transferred to the rheometer. The milk surface was covered with cold vegetable oil to prevent any evaporation. The acidified milks were warmed up from 0 to $30^{\circ} \mathrm{C}$ with a heating rate of $0.5^{\circ} \mathrm{C} / \mathrm{min}$, and the samples were subsequently held at $30^{\circ} \mathrm{C}$ for $17 \mathrm{~h}$. During the warming and holding steps, samples were oscillated at an angular frequency of $1 \mathrm{rad} / \mathrm{s}$ and an applied strain of $0.5 \%$. Measurements were taken every $1 \mathrm{~min}$ during the warming-up step, that is, where gelation of the samples occurred, and every 5 min during the holding step at $30^{\circ} \mathrm{C}$. Gelation was operationally defined, based on instrument sensitivity, as the moment when the storage moduli $\left(\mathbf{G}^{\prime}\right)$ values of gels was greater than $1 \mathrm{~Pa}$ (Lucey et al., 1998). Loss tangent (LT) values were also recorded during the warming and holding stages.

The large deformation properties were determined for gels made in situ in the rheometer. A constant shear rate of $0.01 \mathrm{~s}^{-1}$ was applied to the gels after the holding step at $30^{\circ} \mathrm{C}$ for $17 \mathrm{~h}$. Yield stress was defined as the point when the shear stress started to decrease (by at least 0.5 Pa; Lee and Lucey, 2004).

\section{Microstructural Analysis of Gels}

The microstructure of the gels was studied using the fluorescent microscopy method as described by Choi et al. (2007). The microscope Axioskop 2 plus (Carl Zeiss, Göttingen, Germany) was used. Acridine orange (Sigma-Aldrich) was used as a fluorescent protein stain. Acridine orange $(300 \mu \mathrm{L}$ of $0.2 \%$ acridine orange solution dissolved in deionized water) was added to 50 $\mathrm{mL}$ of cold, acidified milk mixtures. One drop of the mixture was transferred to a microscope slide with a concavity (a coverslip was sealed over the concavity to prevent evaporation); the slide was warmed up from $\sim 0$ to $30^{\circ} \mathrm{C}$ at $0.5^{\circ} \mathrm{C} / \mathrm{min}$ using the plate (peltier) heating system of the rheometer (which was also covered with a plastic box to help improve temperature stability). When the temperature reached $30^{\circ} \mathrm{C}$, the slide was transferred to an incubator (Precision model 815, Thermo Scientific, Waltham, MA) held at $30^{\circ} \mathrm{C}$ and stored for $17 \mathrm{~h}$. The microstructure of the gels was then examined. Excitation and emission wavelengths of 450 and $515 \mathrm{~nm}$, respectively, were used for microstructural analysis. The Choi et al. (2007) imaging method in- volves the deconvolution of 3-dimensional fluorescence microscopy images using several computational restoration techniques.

\section{Statistical Analysis}

An ANOVA was carried out using SigmaPlot 11.0 (Systat Software, San Jose, CA). Each experiment was repeated at least 3 times. The level of significant difference was determined at $P<0.05$. The differences between means were analyzed using Fisher's least significant difference for multiple comparisons of means.

\section{RESULTS}

\section{Gelation Temperature}

Gelation occurred during the warming of acidified milk samples from 0 to $30^{\circ} \mathrm{C}$ at a heating rate of $0.5^{\circ} \mathrm{C} /$ min. Gelation temperatures of the control and the gels made with DX or DS are shown in Table 1 (it should be noted that a different heating rate may have resulted in a slight difference in the gelation temperatures of these samples, so the reported gelation temperatures can be viewed as apparent values for this particular heating rate). Gelation temperatures decreased with a decrease in $\mathrm{pH}$ values.

At all $\mathrm{pH}$ levels, lower gelation temperatures were observed for the gels made with $0.5 \%$ DX compared with the control gels (Table 1). At all pH levels, the addition of low levels of DX $(0.075 \%)$ resulted in gels with comparable gelation temperatures to the control gels. At $\mathrm{pH} 4.4(\mathrm{pH}<\mathrm{pI})$, the gelation temperature for the sample made with $0.5 \%$ DS was similar to the control. At $\mathrm{pH} 4.6(\mathrm{pH}=\mathrm{pI})$, the sample made with $0.5 \%$ DS gelled at a significantly $(P<0.05)$ higher temperature than the control. The gelation temperatures for samples made with $0.5 \% \mathrm{DS}$ at $\mathrm{pH} 4.8$ and $4.9(\mathrm{pH}$ $<\mathrm{pI})$ were significantly $(P<0.05)$ lower than those of the controls, especially at $\mathrm{pH} 4.9$, where the value of $\sim 3.9^{\circ} \mathrm{C}$ was observed compared with $25^{\circ} \mathrm{C}$ for the control gel. Gels made with $0.075 \%$ DS had comparable, or slightly higher, gelation temperatures compared with the control gels, at all $\mathrm{pH}$ levels.

\section{Rheological Properties}

The aged gel stiffness, determined by the $\mathrm{G}^{\prime}$ values after holding at $30^{\circ} \mathrm{C}$ for $17 \mathrm{~h}$, is shown in Table 2 . The $\mathrm{G}^{\prime}$ values for all samples started to increase at lower temperatures (i.e., initiating gel formation) in samples made at lower $\mathrm{pH}$ values compared with samples made at higher $\mathrm{pH}$ (results not shown). At $\mathrm{pH} 4.9$, very weak gels were formed and gelation only occurred at high 
Table 1. Effect of dextran (DX) and dextran sulfate (DS) addition to cold, acidified milks on the gelation temperature during the heating phase from 0 to $30^{\circ} \mathrm{C}$ at $0.5^{\circ} \mathrm{C} / \mathrm{min}$

\begin{tabular}{|c|c|c|c|c|c|}
\hline \multirow[b]{2}{*}{$\mathrm{pH}$} & \multicolumn{5}{|c|}{ Gelation temperature ${ }^{1}\left({ }^{\circ} \mathrm{C}\right)$} \\
\hline & Control & $0.075 \% \mathrm{DX}$ & $0.5 \% \mathrm{DX}$ & $0.075 \%$ DS & $0.5 \% \mathrm{DS}$ \\
\hline 4.4 & $8.5 \pm 0.8^{\mathrm{ab}, \mathrm{D}}$ & $8.0 \pm 0.4^{\mathrm{ab}, \mathrm{D}}$ & $3.4 \pm 1.1^{\mathrm{c}, \mathrm{D}}$ & $9.2 \pm 1.0^{\mathrm{a}, \mathrm{D}}$ & $7.4 \pm 1.0^{\mathrm{b}, \mathrm{c}}$ \\
\hline 4.6 & $12.8 \pm 0.9^{\mathrm{c}, \mathrm{C}}$ & $13.3 \pm 0.8^{\mathrm{bc}, \mathrm{C}}$ & $10.0 \pm 0.8^{\mathrm{d}, \mathrm{C}}$ & $14.2 \pm 0.8^{\mathrm{b}, \mathrm{C}}$ & $18.8 \pm 1.0^{\mathrm{a}, \mathrm{A}}$ \\
\hline 4.8 & $22.0 \pm 1.5^{\mathrm{a}, \mathrm{B}}$ & $21.6 \pm 2.0^{\mathrm{a}, \mathrm{B}}$ & $17.5 \pm 1.1^{\mathrm{b}, \mathrm{B}}$ & $21.7 \pm 1.3^{\mathrm{a}, \mathrm{B}}$ & $16.3 \pm 0.5^{\mathrm{b}, \mathrm{B}}$ \\
\hline 4.9 & $25.0 \pm 1.2^{\mathrm{b}, \mathrm{A}}$ & $26.0 \pm 0.9^{\mathrm{b}, \mathrm{A}}$ & $20.8 \pm 0.3^{\mathrm{c}, \mathrm{A}}$ & $28.4 \pm 0.8^{\mathrm{a}, \mathrm{A}}$ & $3.9 \pm 2.0^{\mathrm{d}, \mathrm{L}}$ \\
\hline
\end{tabular}

temperatures $\left(\geq 25^{\circ} \mathrm{C}\right)$ in the control and samples made with DX (at both concentrations) or with $0.075 \%$ DS.

The $\mathrm{G}^{\prime}$ profiles during storage at $30^{\circ} \mathrm{C}$ indicated that at $\mathrm{pH} 4.4$, the $\mathrm{G}^{\prime}$ values of gels made with $0.5 \% \mathrm{DS}$ increased quickly and attained significantly $(P<0.05)$ higher $\mathrm{G}^{\prime}$ values than the other samples (Table 2 ). As the $\mathrm{pH}$ values increased, the $\mathrm{G}^{\prime}$ profiles of all samples decreased. At high $\mathrm{pH}$ values (4.8 and 4.9$)$, the $\mathrm{G}^{\prime}$ profiles of the gels made with $0.5 \%$ DS hardly changed during holding at $30^{\circ} \mathrm{C}$ and $\mathrm{G}^{\prime}$ values remained very low (results not shown).

The $\mathrm{G}^{\prime}$ values after holding at $30^{\circ} \mathrm{C}$ for $17 \mathrm{~h}$ for the control gel increased in the following order $\mathrm{pH} 4.6>\mathrm{pH}$ $4.4=\mathrm{pH} 4.8>\mathrm{pH} 4.9$. A similar trend $(P<0.05)$ was observed for gels made with $0.075 \%$ DX. For the gels made with $0.5 \%$ DS, very stiff gels were observed at $\mathrm{pH}$ 4.4 , and extremely weak $(<10 \mathrm{~Pa})$ gels were observed at $\mathrm{pH}$ values 4.8 and 4.9 .

Loss tangent profiles of gels during the holding period at $30^{\circ} \mathrm{C}$ are shown in Figure 1. All samples exhibited a decrease in LT values during the holding period. Gels made at high $\mathrm{pH}$ values (Figure 1d) had higher initial LT values compared with gels made at low $\mathrm{pH}$ values (Figure 1a). A decrease in the LT values of a gel over time indicated an increase in its elastic nature. In gels made with $0.5 \%$ DS at pH 4.9 (Figure 1d), little change was observed in LT values during the holding period. However, at pH 4.4 (Figure 1a) and pH 4.6 (Figure 1b), the LT profiles for samples with $0.5 \%$ DS were slightly higher than the control gels.

The yield stress values of various gels are shown in Table 3. Yield stress values of the control gels made at $\mathrm{pH} 4.4$ and 4.6 were similar, and the yield stress values tended $(P<0.05)$ to decrease when the $\mathrm{pH}$ levels were increased to 4.8 and 4.9. In gels made with addition of $0.5 \%$ DX, yield stress of the gels was significantly lower at $\mathrm{pH} 4.4$ than the other $\mathrm{pH}$ values, which were all similar. A similar trend $(P<0.05)$ was also observed with the lower DX concentration. Yield stress values of the gels made with DS decreased as the $\mathrm{pH}$ levels increased, with the $\mathrm{pH} 4.4$ samples having the highest yield stress values for both 0.075 and $0.5 \%$ DS samples. For gels made with $0.5 \%$ DS, very low yield stresses $(\sim 1$ $\mathrm{Pa}$ ) were observed at $\mathrm{pH} 4.8$ and 4.9 .

\section{Microstructure}

The microstructure of the gels analyzed after storage for $17 \mathrm{~h}$ at $30^{\circ} \mathrm{C}$ is shown in Figure 2. Control (Figure $2 \mathrm{a}, \mathrm{f}, \mathrm{k}$, and $\mathrm{p}$ ) and gels made with $0.075 \%$ DX (Figure $2 \mathrm{~b}, \mathrm{~g}, \mathrm{l}$, and $\mathrm{q}$ ) had a similar, fine network structure at all $\mathrm{pH}$ values. Addition of $0.5 \% \mathrm{DX}$ resulted in a very coarse structure for gels made at $\mathrm{pH} 4.4$ (Figure 2c), but at higher $\mathrm{pH}$ levels, the gels appeared more uniformly distributed or finer protein matrix (Figure $2 \mathrm{~h}, \mathrm{~m}$, and $\mathrm{r}$ ). With addition of $0.075 \%$ DS, small and

Table 2. Effect of dextran (DX) or dextran sulfate (DS) addition to cold, acidified milks on gel stiffness $\left(\mathrm{G}^{\prime}\right.$ values) of gels after heating to $30^{\circ} \mathrm{C}$ and holding for $17 \mathrm{~h}$ at $30^{\circ} \mathrm{C}$

\begin{tabular}{|c|c|c|c|c|c|}
\hline \multirow[b]{2}{*}{$\mathrm{pH}$} & \multicolumn{5}{|c|}{ Gel stiffness, $\mathrm{G}^{\prime}(\mathrm{Pa})$, after storage for $17 \mathrm{~h}$ at $30^{\circ} \mathrm{C}$} \\
\hline & Control & $0.075 \% \mathrm{DX}$ & $0.5 \% \mathrm{DX}$ & $0.075 \%$ DS & $0.5 \% \mathrm{DS}$ \\
\hline 4.4 & $246 \pm 32^{\mathrm{b}, \mathrm{B}}$ & $231 \pm 36^{\mathrm{b}, \mathrm{B}}$ & $152 \pm 46^{\mathrm{c}, \mathrm{C}}$ & $271 \pm 14^{\mathrm{b}, \mathrm{A}}$ & $405 \pm 40^{\mathrm{a}, \mathrm{A}}$ \\
\hline 4.6 & $289 \pm 34^{\mathrm{a}, \mathrm{A}}$ & $282 \pm 20^{\mathrm{a}, \mathrm{A}}$ & $204 \pm 13^{\mathrm{b}, \mathrm{A}}$ & $254 \pm 15^{\mathrm{a}, \mathrm{A}}$ & $132 \pm 31^{\mathrm{c}, \mathrm{B}}$ \\
\hline 4.8 & $221 \pm 29^{\mathrm{a}, \mathrm{B}}$ & $235 \pm 16^{\mathrm{a}, \mathrm{B}}$ & $190 \pm 6^{\mathrm{b}, \mathrm{AB}}$ & $173 \pm 20^{\mathrm{b}, \mathrm{B}}$ & $7 \pm 1^{\mathrm{c}, \mathrm{C}}$ \\
\hline 4.9 & $164 \pm 15^{\mathrm{a}, \mathrm{C}}$ & $132 \pm 12^{\mathrm{b}, \mathrm{C}}$ & $169 \pm 9^{\mathrm{a}, \mathrm{BC}}$ & $55 \pm 15^{\mathrm{c}, \mathrm{C}}$ & $4 \pm 1^{\mathrm{d}, \mathrm{C}}$ \\
\hline
\end{tabular}


Table 3. Effect of dextran (DX) or dextran sulfate (DS) addition to cold, acidified milks on yield stress of gels formed after heating to $30^{\circ} \mathrm{C}$ and holding for $17 \mathrm{~h}$ at $30^{\circ} \mathrm{C}$

\begin{tabular}{llcccc}
\hline \multicolumn{5}{c}{ Yield stress $(\mathrm{Pa})$} \\
\cline { 2 - 6 } $\mathrm{pH}$ & Control & $0.075 \% \mathrm{DX}$ & $0.5 \% \mathrm{DX}$ & $0.075 \% \mathrm{DS}$ & $0.5 \% \mathrm{DS}$ \\
\hline 4.4 & $168 \pm 21^{\mathrm{a}, \mathrm{A}}$ & $69 \pm 42^{\mathrm{b}, \mathrm{B}}$ & $9 \pm 2^{\mathrm{c}, \mathrm{B}}$ & $160 \pm 6^{\mathrm{a}, \mathrm{A}}$ & $88 \pm 4^{\mathrm{b}, \mathrm{A}}$ \\
4.6 & $169 \pm 2^{\mathrm{a}, \mathrm{A}}$ & $154 \pm 14^{\mathrm{ab}, \mathrm{A}}$ & $97 \pm 6^{\mathrm{c}, \mathrm{A}}$ & $142 \pm 10^{\mathrm{b}, \mathrm{B}}$ & $32 \pm 15^{\mathrm{d}, \mathrm{B}}$ \\
4.8 & $146 \pm 15^{\mathrm{a}, \mathrm{B}}$ & $147 \pm 13^{\mathrm{a}, \mathrm{A}}$ & $95 \pm 11^{\mathrm{b}, \mathrm{A}}$ & $88 \pm 8^{\mathrm{b}, \mathrm{C}}$ & $1 \pm 0^{\mathrm{c}, \mathrm{C}}$ \\
4.9 & $122 \pm 7^{\mathrm{a}, \mathrm{C}}$ & $119 \pm 3^{\mathrm{a}, \mathrm{A}}$ & $94 \pm 6^{\mathrm{b}, \mathrm{A}}$ & $35 \pm 9^{\mathrm{c}, \mathrm{D}}$ & $1 \pm 0^{\mathrm{d}, \mathrm{C}}$ \\
\hline
\end{tabular}

${ }^{\mathrm{a}-\mathrm{d}}$ Different lowercase superscripts in the same row indicate significant differences $(P<0.05)$.

${ }^{\mathrm{A}-\mathrm{D}}$ Different uppercase superscripts in the same column indicate significant differences $(P<0.05)$.

fine casein aggregates were observed with few dense clusters (Figure 2d, i, n, and s). All gels made with $0.5 \%$ DS (Figure $2 \mathrm{e}, \mathrm{j}, \mathrm{o}$, and $\mathrm{t}$ ) possessed very coarse network structure.

\section{DISCUSSION}

The effect of added DX or DS on the gelation, rheological, and microstructural properties of gels made

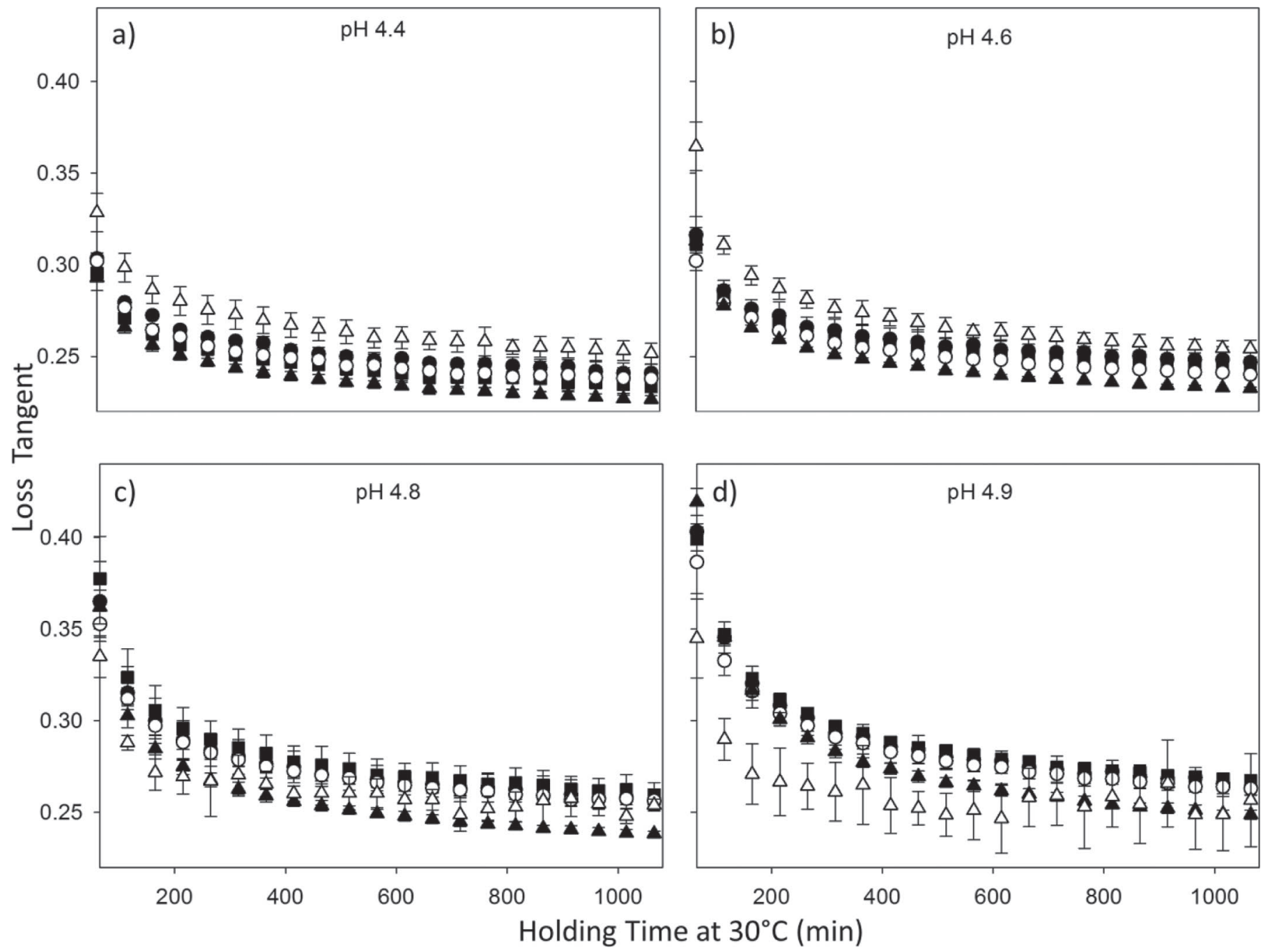

Figure 1. Loss tangent as a function of time for gels made from acidified milks at pH 4.4 (a), 4.6 (b), 4.8 (c), and 4.9 (d) for control samples (ם) and samples of gels made with $0.075 \%$ dextran (DX; $\bullet$ ), $0.5 \%$ DX (O), $0.075 \%$ dextran sulfate (DS; $\mathbf{\Delta})$, and $0.5 \%$ DS $(\Delta)$ held at $30^{\circ} \mathrm{C}$ for $17 \mathrm{~h}$ (after heating from $\sim 0$ to $30^{\circ} \mathrm{C}$ ); error bars indicate standard deviations. 


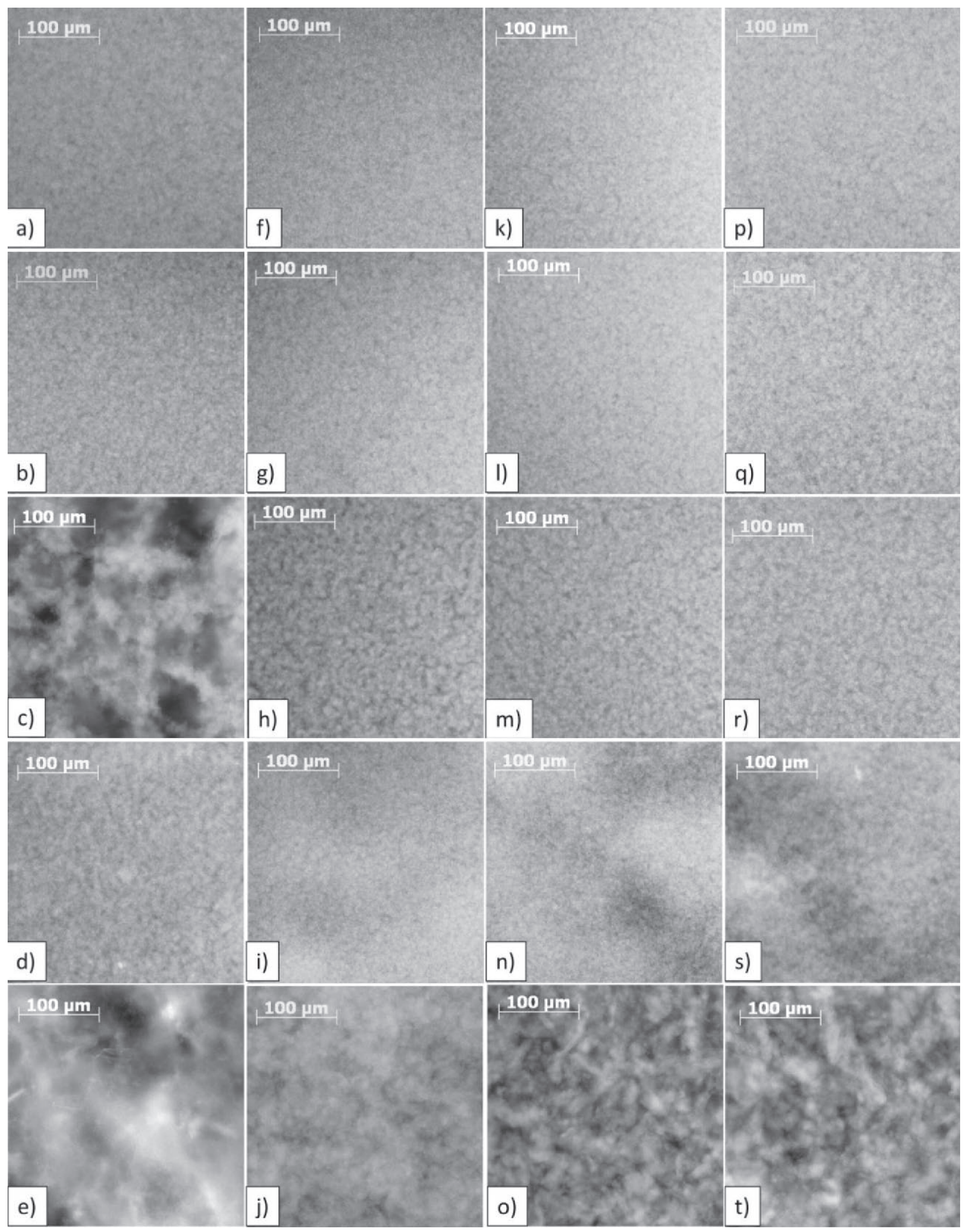

Figure 2. Microstructure of gels made from cold, acidified milk and with added dextran (DX) and dextran sulfate (DS) at pH 4.4 (a, b, c, $\mathrm{d}$, and e), $\mathrm{pH} 4.6$ (f, g, h, i, and j), pH 4.8 (k, l, m, n, and o), and pH 4.9 (p, q, r, s, and t) for control (a, f, k, and p), 0.075\% DX (b, g, l, and q), $0.5 \%$ DX (c, h, m, and r), 0.075\% DS (d, i, n, and s), and 0.5\% DS (e, j, o, and t). The protein matrix is white and pores are dark. Scale bar $=100 \mu \mathrm{m}$. 
from cold, acidified milks was investigated. The study was performed at different $\mathrm{pH}$ levels to investigate conditions above and below the $\mathrm{pI}$ of caseins, as the charge on caseins varies with $\mathrm{pH}$ and, thus, the type of interactions with DS could vary. In the cold, acidified milk system, without the addition of DX or DS, $\beta$-caseins likely protrude from the surface of casein particles at low temperature (Roefs et al., 1990). Steric repulsion from both $\beta$-caseins and $\kappa$-casein hairs protruding from caseins may help prevent the gelation of acidified milk at low temperature. Also, Ca binding by caseins is reduced at low temperature (Parker and Dalgleish, 1981), which might increase electrostatic repulsion and reduce casein aggregation (Horne and Lucey, 2014). As temperature increased, the casein particles started to aggregate as a result of increased hydrophobic interactions, and possibly a slight increase in Ca binding, resulting in the formation of protein strands and conglomerates, which led to a continuous gel network (Roefs et al., 1990).

Addition of high concentration of DX (0.5\% DX) to cold, acidified milk lowered the gelation temperature (i.e., milks gelled sooner) compared with control samples at all $\mathrm{pH}$ levels (Table 1). Dextran used in this study is an uncharged and nonadsorbing polysaccharide. Depletion flocculation induced by caseins and the presence of nonadsorbing polysaccharides (DX) is the likely driving force for faster aggregation in these samples. Protein-polysaccharide contacts are energetically unfavorable compared with the interaction between protein-solvent and polysaccharide-solvent (Grinberg and Tolstoguzov, 1997). The high-molar-mass DX molecules were likely excluded from the surface of the large casein clusters (which were observed in control samples, Figures 2a, f, k, and p). The osmotic pressure in this depleted area was thus lower than in the bulk because of a lower concentration of DX in this depleted region (Tuinier et al., 2003). These depleted layers can overlap because of Brownian motion of casein clusters. This overlap volume of 2 depleted layers increases the bulk volume available to DX and, thus, decreases the free energy of the system. As a result, casein clusters tend to attract one another (Corredig et al., 2011), and this was likely the factor that led to the faster gelation in the samples made with $0.5 \%$ DX. Depletion flocculation was also observed in the dispersions of cold $\left(0^{\circ} \mathrm{C}\right)$ milk proteins with high concentration of DX (1.0-2.0\%) over the $\mathrm{pH}$ range from 4.4 to 4.9 (Pachekrepapol et al., 2014). Although, addition of high concentrations of polysaccharide $(\geq 1.0 \%)$ may slow down the aggregation of caseins by increasing the viscosity of the system, depletion-type effects still influenced the system by promoting the aggregation or gelation of caseins at low temperature (Pachekrepapol et al., 2014).
With lower concentration of DX $(0.075 \%$ DX), the gelation temperature was not significantly different $(P>0.05)$ from the control gels (Table 1$)$. This indicated that low concentrations of this polysaccharide were insufficient to cause depletion-flocculation-type effect. In this case, the small increase in viscosity (due to the added polysaccharide) might counteract any slight increase in the rate of aggregation induced by a weak depletion-flocculation effect. These results are in agreement with Girard and Schaffer-Lequart (2007), who observed no significant difference in the gelation of acidified milk made with low concentrations of DX $(0.01$ and $0.05 \%)$ when milks were acidified with glucono- $\delta$-lactone. Pachekrepapol et al. (2014) also found that at low concentration of DX, acidified milk proteins did not aggregate when held at $\sim 0^{\circ} \mathrm{C}$. Mende et al. (2013) found that gelation time decreased as the DX concentration increased in gels made by either bacterial fermentation or by the addition of glucono- $\delta$ lactone. However, when the polysaccharide concentration exceeds a certain concentration (also dependent on its molar mass), depletion flocculation could also lead to phase separation of the system, which results in (separate) protein-rich and polysaccharide-rich phases (de Kruif and Tuinier, 2001). It should be noted that in the studies conducted by Girard and Schaffer-Lequart (2007) and Mende et al. (2013), a lower molar mass DX $\left(\sim 0.5 \times 10^{6} \mathrm{Da}\right)$ was used compared with the DX used in the present study $\left(2 \times 10^{6} \mathrm{Da}\right)$, and that molar mass is one of the important physical properties of polysaccharides influencing its radius of gyration and viscosity (Ruas-Madiedo et al., 2002).

Aged gel stiffness (i.e., $\mathrm{G}^{\prime}$ values after $17 \mathrm{~h}$ storage at $30^{\circ} \mathrm{C}$ ) and yield-stress values of gels made with $0.5 \%$ DX were lower than the control gels at $\mathrm{pH} 4.4,4.6$, and 4.8 (Tables 2 and 3). The $\mathrm{G}^{\prime}$ values of gels are proportional to the number, type, and spatial arrangement of bonds in the network (Lucey et al., 2003). Depletion flocculation occurred when $0.5 \%$ DX was added to the acidified milk samples, and the induced attraction of caseins resulted in earlier gelation of the samples during the heating step. A lower stiffness of gels containing high concentrations of some types of polysaccharides was observed in gels made with EPS-producing strains (Hassan et al., 2001; Purohit et al., 2009) and in acid gels made with the addition of $\beta$-glucan (Lazaridou et al., 2014). This lower stiffness suggests that the presence of (uncharged) polysaccharides interfered with casein-casein interactions (Purohit et al., 2009) as the continuity of the gel network was interrupted by the presence of nonadsorbing DX (e.g., inert filler particles), resulting in gels with fewer cross-links (Lazaridou et al., 2008). The microstructures of the gels made with $0.5 \%$ 
$\mathrm{DX}$ at $\mathrm{pH} 4.4,4.6$, and 4.8 (Figure $2 \mathrm{c}, \mathrm{h}$, and $\mathrm{m}$ ) were consistent with the rheological results, in that coarser structures were formed with large pore sizes, compared with the control gels, at the same pH levels (Figure 2a, $\mathrm{f}$, and k). For example, very coarse structure and denser clusters were observed at $\mathrm{pH} 4.4$ for gels made with $0.5 \%$ DX (Figure 2c). In some systems, a fine-stranded type of protein network can contribute to a higher $\mathrm{G}^{\prime}$ values because of greater number of potential proteinprotein bonds or cross-links in the network matrix (Hassan et al., 2003). Coarser structures could mean fewer interconnections between the large clusters making up the network resulting in an overall weaker gel. Mende et al. (2013) reported that gel stiffness increased with increasing DX concentration (from 0 to $3 \%$ DX), and these authors suggested that the higher stiffness was due to the relatively small molar mass of DX $\left(0.5 \times 10^{6}\right.$ Da; compared with other types of polysaccharides, such as EPS produced from lactic acid bacteria), which did not excessively hinder protein aggregation.

The DS used in this study was highly charged containing $\sim 18 \%$ sulfur ( $\sim 1.9$ sulfate groups per glucosyl unit). When the $\mathrm{pH}$ of milk decreased, net negative charge of caseins decreased, so negatively charged DS could interact with positive charges or patches on caseins (Dickinson, 1998). At pH levels below the $\mathrm{pI}$ of caseins, i.e., $\mathrm{pH} 4.4$, the net charge of caseins becomes slightly positive (or carries more positive charges than negative charges). Caseins did not gel at low $\mathrm{pH}$ values when held at low temperature $\left(\sim 0^{\circ} \mathrm{C}\right)$. When DS solution was added into acidified milk, sulfate groups in the polysaccharide molecules could associatively interact with positively charged local patches or areas on caseins particles. Because DS molecules had a high molar mass and were highly charged, a molecule of DS could potentially interact with more than one casein particle, and a casein particle might also interact with more than one DS molecule (Figure 3a). Based on this proposed interaction model, bridging interactions could result in strong casein-DS electrostatic interactions and stiff gel network. Gelation temperature of the sample made with $0.5 \%$ DS was slightly, but not significantly, lower than the control gel at $\mathrm{pH} 4.4$ (Table 1), and the $\mathrm{G}^{\prime}$ value after $17 \mathrm{~h}$ of storage was very high compared with all other samples (Table 2). This indicated that DS modified gelation and helped reinforce the gel network. Electrostatic interactions between caseins and DS at $\mathrm{pH}$ values between 4.4 and 4.9 were also observed in the recent study of acidified milk protein dispersions with DS (Pachekrepapol et al., 2014). The yield-stress value for the gel made at $\mathrm{pH} 4.4$ with $0.5 \%$ DS was lower than the control gel (Table 3). The strength of protein-protein bonds, the number of bonds per cross- section, and the orientation of the protein strands in the network all contribute to the yield-stress value (van Vliet et al., 1991). The microstructure of gels made at $\mathrm{pH} 4.4$ with $0.5 \%$ DS (Figure 2e) appeared to have large protein strands in the network with large pore sizes, and less contact areas between caseins, which likely modified its yielding behavior.

At $\mathrm{pH}>\mathrm{pI}(\mathrm{pH} 4.8$ and 4.9), caseins carried a slight net negative charge but some positive charges would still exist. Casein particles can form weak acid gels at these $\mathrm{pH}$ values, indicating attractive interactions, such as electrostatic attractions (positive-negative interactions), dominate over repulsive interaction (such as, negative-negative interactions). Localized positive patches on caseins could interact with negatively charged DS, see schematic model in Figure 3b. Although, DS molecules might be adsorbed onto casein patches to form protein-polysaccharide complexes; these complexes would then have an overall repulsive interaction because of the multiple negative charges on DS molecules (Goh et al., 2008). Very weak gels were formed at high $\mathrm{pH}$ with the addition of DS. The weak gel was formed as a result of casein-casein interactions; the system never strengthened even after $17 \mathrm{~h}$ of storage at $30^{\circ} \mathrm{C}$ because the adsorbed DS molecules would provide additional charge repulsion blocking or hindering any further aggregation of caseins (Figure $3 b$ ). The very low $\mathrm{G}^{\prime}$ values, which did not increase during storage at $30^{\circ} \mathrm{C}$, suggested that the samples remained close to a type of unstable weak gel or dispersion, unlike the other samples whose $\mathrm{G}^{\prime}$ values rapidly increased during storage. These very low $\mathrm{G}^{\prime}$ values were also in agreement with their microstructures (Figures 2o and t), where coarse structures with little interconnectivity were observed. In mixed biopolymer gel systems that undergo segregative phase separation (e.g., de Jong and van de Velde, 2007), very weak gel networks have also been reported.

Loss-tangent values indicate the viscoelastic character of the gel material; for example, more solid-like or liquid-like (Lucey, 2001). At the higher $\mathrm{pH}$ levels ( $\mathrm{pH}$ 4.8 or 4.9 ), the LT profiles of the samples made with $0.5 \%$ DS (Figure 1c and 1d) hardly changed over time as a result of the nonincreasing $\mathrm{G}^{\prime}$ values. In acidified milk dispersions made at $\mathrm{pH}$ values 4.8 and 4.9 ( $\mathrm{pH}$ above the $\mathrm{pI}$ of caseins), coating of DS onto caseins were also reported to inhibit casein aggregation (Pachekrepapol et al., 2014).

At $\mathrm{pH} 4.8$ or 4.9 , the addition of $0.075 \%$ DS to acidified caseins lowered the stiffness of the acid gel compared with the control sample (Table 2). These results indicated that at $\mathrm{pH}$ values $>\mathrm{pI}$, the addition of even low concentrations of highly negatively charged sul- 

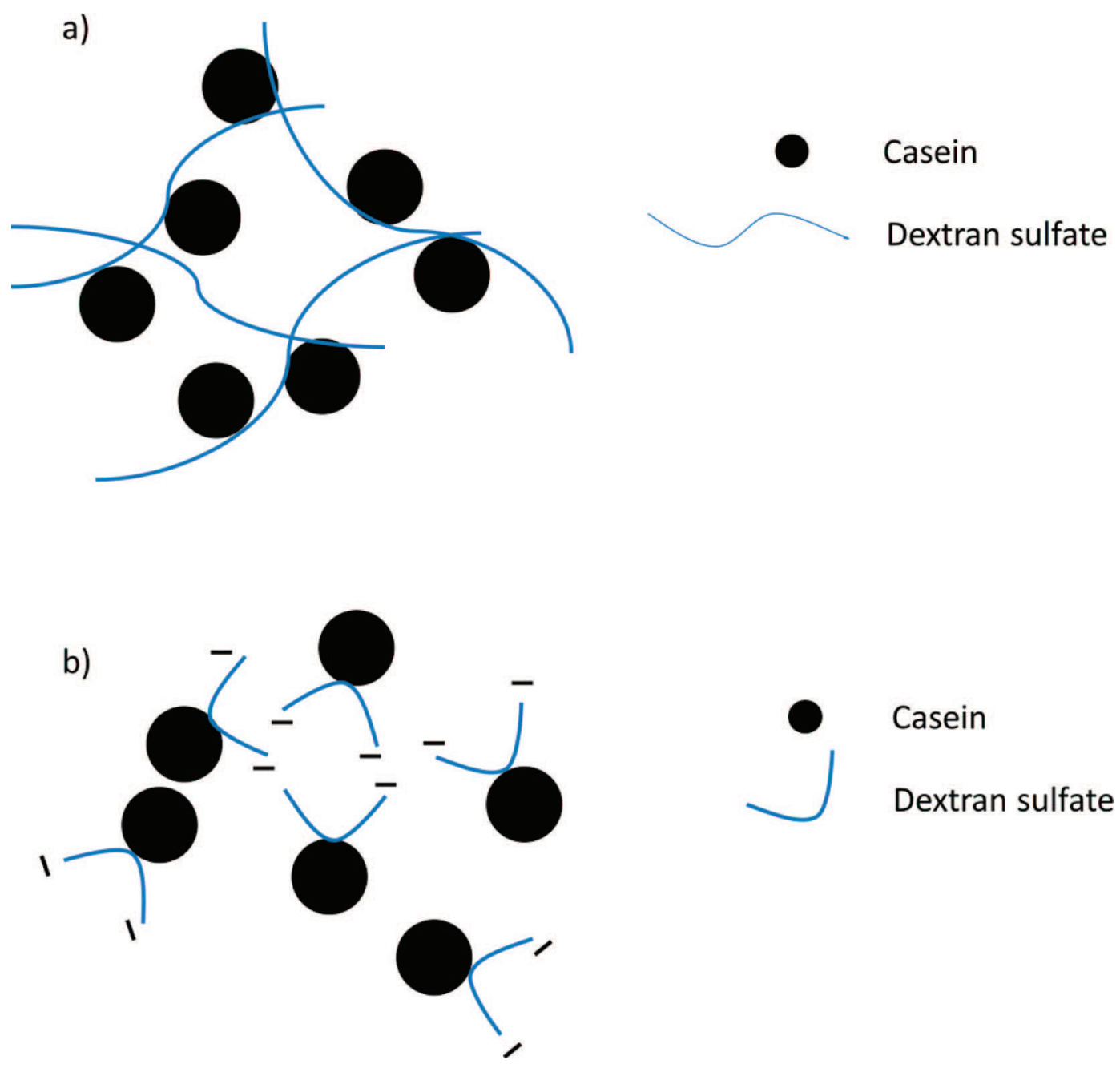

Figure 3. Model of possible interaction between caseins and dextran sulfate at (a) low $\mathrm{pH}$ ( $\mathrm{pH}$ less than isoelectric point) and (b) high $\mathrm{pH}$ ( $\mathrm{pH}$ greater than isoelectric point). Color version available online.

fated polysaccharide negatively affected the gel properties because of the additional negative charge repulsion introduced into the system.

\section{CONCLUSIONS}

The effect of the addition of DX to model acid gels can be explained by a depletion-flocculation mechanism, which caused earlier gelation but resulted in weaker gels because of altered microstructure of the matrix. Electrostatic interactions caused by addition of negatively charged DS can alter gel properties depending on the $\mathrm{pH}$ of the milk system. Attractive interactions between negatively charged DS and positive charges (patches) on caseins occurred at $\mathrm{pH}<\mathrm{pI}$, and these cross-links resulted in stiffer acid gels. At $\mathrm{pH}>\mathrm{pI}$, coating of caseins with negatively charged DS inhibited further aggregation of caseins by introducing more repulsive interactions between these casein-DS complexes.

\section{ACKNOWLEDGMENTS}

This material is based upon work supported by the National Institute of Food and Agriculture, USDA, under project WIS01650 (Hatch).

\section{REFERENCES}

Aichinger, P.-A., M.-L. Dillmann, S. Rami-Shojaei, A. Paterson, M. Michel, and D. S. Horne. 2007. Xanthan gum in skim milk: Designing structure into acid milk gels. Pages 289-302 in Food Colloids: Self-Assembly and Material Science. E. Dickinson and M. E. Leser, ed. Royal Soc. Chem., Cambridge, UK.

Choi, J., D. S. Horne, and J. A. Lucey. 2007. Effect of insoluble calcium concentration on rennet coagulation properties of milk. J. Dairy Sci. 90:2612-2623. 
Corredig, M., N. Sharafbafi, and E. Kristo. 2011. Polysaccharide-protein interactions in dairy matrices, control and design of structures. Food Hydrocoll. 25:1833-1841.

de Jong, S., and F. van de Velde. 2007. Charge density of polysaccharide controls microstructure and large deformation properties of mixed gels. Food Hydrocoll. 21:1172-1187.

de Kruif, C. G., and R. Tuinier. 2001. Polysaccharide protein interactions. Food Hydrocoll. 15:555-563.

Dickinson, E. 1998. Stability and rheological implications of electrostatic milk protein-polysaccharide interactions. Trends Food Sci. Technol. 9:347-354.

Girard, M., and C. Schaffer-Lequart. 2007. Gelation of skim milk containing anionic exopolysaccharides and recovery of texture after shearing. Food Hydrocoll. 21:1031-1040.

Girard, M., and C. Schaffer-Lequart. 2008. Attractive interactions between selected anionic exopolysaccharides and milk proteins. Food Hydrocoll. 22:1425-1434.

Goh, K., A. Sarkar, and H. Singh. 2008. Milk protein-polysaccharide interactions. Pages 347-376 in Milk Proteins: From Expression to Food. A. Thompson, M. Boland, and H. Singh, ed. Acad. Press, New York, NY.

Grinberg, V. Ya., and V. B. Tolstoguzov. 1997. Thermodynamic incompatibility of proteins and polysaccharides in solutions. Food Hydrocoll. 11:145-158.

Hassan, A. N., M. Corredig, and J. F. Frank. 2001. Viscoelastic properties of yogurt made with ropy and non-ropy exopolysaccharides producing cultures. Milchwissenschaft 56:684-687.

Hassan, A. N., R. Ipsen, T. Janzen, and K. B. Qvist. 2003. Microstructure and rheology of yogurt made with cultures differing only in their ability to produce exopolysaccharides. J. Dairy Sci. 86:1632-1638

Horne, D. S., and J. A. Lucey. 2014. Revisiting the temperature dependence of the coagulation of renneted bovine casein micelles. Food Hydrocoll. 42:75-80.

Jourdain, L., M. E. Leser, C. Schmitt, M. Michel, and E. Dickinson. 2008. Stability of emulsions containing sodium caseinate and dextran sulfate: Relationship to complexation in solution. Food Hydrocoll. 22:647-659.

Kristo, E., Z. Miao, and M. Corredig. 2011. The role of exopolysaccharide produced by Lactococcus lactis ssp. cremoris in structure formation and recovery of acid milk gels. Int. Dairy J. 21:656-662.

Lazaridou, A., A. Serafeimidou, C. G. Biliaderis, T. Moschakis, and N. Tzanetakis. 2014. Structure development and acidification kinetics in fermented milk containing oat $\beta$-glucan, a yogurt culture and a probiotic strain. Food Hydrocoll. 39:204-214.

Lazaridou, A., H. Vaikousi, and C. G. Biliaderis. 2008. Impact of mixed-linkage $(1 \rightarrow 3,1 \rightarrow 4)$ beta-glucans on physical properties of acid-set skim milk gels. Int. Dairy J. 18:312-322.

Lee, W. J., and J. A. Lucey. 2004. Structure and physical properties of yogurt gels: Effect of inoculation rate and incubation temperature. J. Dairy Sci. 87:3153-3164.
Lee, W. J., and J. A. Lucey. 2010. Formation and physical properties of yogurt. Asian-australas. J. Anim. Sci. 23:1127-1136.

Lucey, J. A. 2001. The relationship between rheological parameters and whey separation in milk gels. Food Hydrocoll. 15:603-608.

Lucey, J. A., M. E. Johnson, and D. S. Horne. 2003. Perspectives on the basis of the rheology and texture properties of cheese. J. Dairy Sci. 86:2725-2743.

Lucey, J. A., and H. Singh. 1997. Formation and physical properties of acid milk gels: A review. Food Res. Int. 30:529-542.

Lucey, J. A., M. Tamehana, H. Singh, and P. A. Munro. 1998. A comparison of the formation, rheological properties and microstructure of acid skim milk gels made with a bacterial culture or glucono- $\delta$ lactone. Food Res. Int. 31:147-155.

Mende, S., C. Mentner, S. Thomas, H. Rohm, and D. Jaros. 2012. Exopolysaccharide production by three different strains of Streptococcus thermophilus and its effect on physical properties of acidified milk. Eng. Life Sci. 12:466-474

Mende, S., M. Peter, K. Bartels, T. Dong, H. Rohm, and D. Jaros. 2013. Concentration dependent effects of dextran on the physical properties of acid milk gels. Carbohydr. Polym. 98:1389-1396.

Pachekrepapol, U., D. S. Horne, and J. A. Lucey. 2014. Interactions between acidified dispersions of milk proteins with dextran or dextran sulfate. J. Dairy Sci. 97:5371-5382.

Parker, T. G., and D. G. Dalgleish. 1981. Binding of calcium ions to bovine beta-casein. J. Dairy Res. 48:71-76.

Purohit, D. H., A. N. Hassan, E. Bhatia, X. Zhang, and C. Dwivedi. 2009. Rheological, sensorial, and chemopreventive properties of milk fermented with exopolysaccharide-producing lactic cultures. J. Dairy Sci. 92:847-856.

Roefs, S. P. F. M., A. E. A. De Groot-Mostert, and T. van Vliet. 1990. Structure of acid casein gels: 1. Formation and model of gel network. Colloids Surf. 50:141-159.

Ruas-Madiedo, P., J. Hugenholtz, and P. Zoon. 2002. An overview of the functionality of exopolysaccharides produced by lactic acid bacteria. Int. Dairy J. 12:163-171.

Tamime, A. Y., and R. K. Robinson. 2007. Yoghurt: Science and Technology. 3rd ed. CRC Press, Boca Raton, FL.

Tuinier, R., and C. G. de Kruif. 1999. Phase behavior of casein micelles/exocellular polysaccharide mixtures: Experiment and theory. J. Chem. Phys. 110:9296-9304.

Tuinier, R., J. Rieger, and C. G. de Kruif. 2003. Depletion-induced phase separation in colloid polymer mixtures. Adv. Colloid Interface Sci. 103:1-31.

van Vliet, T., H. J. M. van Dijk, P. Zoon, and P. Walstra. 1991. Relation between syneresis and rheological properties of particle gels. Colloid Polym. Sci. 269:620-627. 